\title{
Influence of Processing Methods on Proximate Composition and Dieting of Two Amaranthus Species from West Cameroon
}

\author{
Arnaud Landry Suffo Kamela, ${ }^{1,2}$ Raymond Simplice Mouokeu, ${ }^{3}$ \\ Rawson Ashish, ${ }^{2}$ Ghislain Maffo Tazoho, ${ }^{1}$ Lamye Glory Moh, ${ }^{1}$ \\ Etienne Pamo Tedonkeng, ${ }^{4}$ and Jules-Roger Kuiate ${ }^{1}$ \\ ${ }^{1}$ Department of Biochemistry, Faculty of Science, University of Dschang, P.O. Box 67, Dschang, Cameroon \\ ${ }^{2}$ Department of Food Engineering and Design, Indian Institute of Crop and Processing Technology, Thanjavur, India \\ ${ }^{3}$ Institute of Fisheries and Aquatic Sciences, University of Douala, P.O. Box 7236, Douala, Cameroon \\ ${ }^{4}$ Department of Animal Production, Faculty of Agronomy and Agricultural Science, University of Dschang, Dschang, Cameroon
}

Correspondence should be addressed to Jules-Roger Kuiate; jrkuiate@yahoo.com

Received 17 July 2016; Accepted 30 October 2016

Academic Editor: Rosana G. Moreira

Copyright (C) 2016 Arnaud Landry Suffo Kamela et al. This is an open access article distributed under the Creative Commons Attribution License, which permits unrestricted use, distribution, and reproduction in any medium, provided the original work is properly cited.

\begin{abstract}
The effects of various processing methods on the proximate composition and dieting of Amaranthus hybridus and Amaranthus cruentus from West Cameroon were investigated in this study. Both amaranths leaves were subjected to same treatments (sun-dried and unsliced, sliced and cooked), milled, and analysed for their mineral and proximate composition. Thirty-Six Wistar albino rats of 21 to 24 days old were distributed in six groups and fed for 14 days with $10 \%$ protein based diets named D0 (protein-free diet), DI (egg white as reference protein), DII (sun-dried and unsliced A. hybridus), DIII (cooked and sliced A. hybridus), DIV (sun-dried and unsliced A. cruentus), and DV (cooked and sliced A. cruentus). The protein bioavailability and haematological and biochemical parameters were assessed in rats. The results showed that $\mathrm{K}, \mathrm{P}, \mathrm{Mg}, \mathrm{Zn}$, and Fe had the higher content in both samples regardless of processing method. The sun-dried and unsliced A. cruentus contained the highest value of crude protein $32.22 \mathrm{~g} / 100 \mathrm{~g}$ DM (dry matter) while the highest crude lipid, 3.80 and $2.58 \%$, was observed, respectively, in sun-dried and unsliced $A$. hybridus and cooked and sliced A. cruentus. Cooked and sliced A. hybridus and A. cruentus contained high crude fiber of 14 and $12.18 \%$, respectively. Rats fed with diet DIII revealed the best protein bioavailability and haematological parameters whereas $100 \%$ mortality rate was recorded with group fed with diet DIV. From this study, it is evident that cooked and sliced A. hybridus and A. cruentus could play a role in weight reduction regimes.
\end{abstract}

\section{Introduction}

Vegetables and fruits offer the most rapid and cheapest sources of adequately supplied vitamins, minerals, and some essential amino acids [1]. They have the cheapest and most abundant sources of protein [2]. In Cameroon, as in many Africa countries, vegetables are very abundant immediately after the first rains, but they become scarce in the middle of the rainy season and more so in the dry season [3].

A great variety of local and introduced vegetable crops are grown in Cameroon and these crops together with a significant number of wild and semiwild plants like Amaranthus hybridus and Amaranthus cruentus form a valuable complementary food in the daily diet [4]. Most of them are consumed in the rural areas or in the communities where they are being planted [5]. They are underutilized when compared to the introduced varieties due to the flavor and unfamiliar taste impacted on the food $[6,7]$. They are very perishable commodities with very high moisture contents; therefore, dehydration results in substantial reduction in weight and bulk with consequent savings in storage costs [8]. As green leafy vegetables are edible parts of the plants and are usually cooked before consumption, cooking causes significant changes in the nutritional properties of food as well as gelatinization of starches and coagulation of proteins to improve their digestibility and sensory properties [9]. 
TABLE 1: Ingredient and composition of diets.

\begin{tabular}{|c|c|c|c|c|c|c|}
\hline \multirow{2}{*}{ Ingredients (g/100 g) } & \multicolumn{6}{|c|}{ Diets } \\
\hline & D0 & DI & DII & DIII & IV & DV \\
\hline Corn starch & 15 & 15 & 15 & 15 & 15 & 15 \\
\hline Corn oil & 5 & 5 & 5 & 5 & 5 & 5 \\
\hline Mineral complex & 4 & 4 & 4 & 4 & 4 & 4 \\
\hline Vitamin complex & 1 & 1 & 1 & 1 & 1 & 1 \\
\hline Cellulose & 7.9 & 7.9 & 7.9 & 7.9 & 7.9 & 7.9 \\
\hline Protein source & - & 13.37 & 32.3 & 31.4 & 30.1 & 38.9 \\
\hline Sucrose & 67.1 & 53.73 & 34.8 & 35.7 & 37 & 28.2 \\
\hline Total & 100 & 100 & 100 & 100 & 100 & 100 \\
\hline
\end{tabular}

D0: protein-free diet, DI: egg white (protein reference) diet, DII: sun-dried and unsliced A. hybridus diet, DIII: cooked and sliced A. hybridus, DIV: sun-dried and unsliced A. cruentus, and DV: cooked and sliced A. cruentus.

Udosen and Ukpanah [10] observed that processing causes losses in some of the antinutritional factors and some good nutrients as well.

In many homes in Cameroon, the outstanding preservative method practiced on green leafy vegetables is slicing or not, followed by sun drying which is often combined with cooking. These methods are found to be effective in improving digestibility and increasing nutrient bioavailability and also minimize foodborne diseases [11]. Through boiling, some antinutrients contents of the leaves can be reduced [12]. However, information appears scanty on the nutritional composition of the vegetable harvested in Cameroon. The aim of this work was to determine the mineral and proximate composition of two leafy vegetables consumed in West Cameroon which undergo slicing, sun drying, and cooking processing techniques as well as protein bioavailability using rats' model. The awareness will encourage the consumption and exploitation of these cheap sources of not well-known food item at any time and throughout the year.

\section{Materials and Methods}

2.1. Plant Leaves Collection and Processing. The leaves of Amaranthus hybridus and Amaranthus cruentus were obtained from cultivated farmlands located at Foto, Dschang City of the West Region of Cameroon, from April 2013 to September 2013. The botanical identification was done at the National Herbarium in Yaounde (Cameroon) by referring to the voucher specimen number $15630 \mathrm{HNC}$.

The collected samples were thoroughly mixed, their stalks and dust discarded, and they were divided into two groups. The first group was sun dried without slicing with frequent turning till leaves were crumbly, while the second group (100 g) was cooked after slicing for 15 min following bleaching in boiling water $(1000 \mathrm{~mL})$ for 10 minutes. Cooked and sliced samples were cooled at ambient temperature $\left(20^{\circ} \mathrm{C} \pm 2\right)$, water was removed, and the sample sun dried for 3 days.

2.2. Assessment of Minerals and Heavy Metals Content. Minerals and heavy metals including $\mathrm{Na}, \mathrm{K}, \mathrm{Ca}, \mathrm{P}, \mathrm{Mg}, \mathrm{Mn}, \mathrm{Fe}$, and $\mathrm{Zn}$ and $\mathrm{As}, \mathrm{Hg}, \mathrm{Pb}$, and $\mathrm{Cd}$, respectively, were analysed using ICP-OES (Perkin-Elmer; Model Optima ${ }^{\text {тм }} 2000$ DV,
Schwerzenbach, Switzerland) [13]. Analyses were performed in triplicate.

2.3. Proximate Composition Analysis. The methods adopted for the proximate composition analysis were those recommended by the Association of Official Analytical Chemists [14]. Analyzed parameters included dry mater, ash content, crude fat, crude fibre, and proteins.

\subsection{Evaluation of Protein Bioavailability}

2.4.1. Experimental Animals. Thirty-six Wistar albinos rats of both sexes, 21 to 24 days old, weighing 34-43g were used in the experiment. These animals were bred in the Animal House of the Department of Biochemistry, University of Dschang, Cameroon, and were fed with a standard rat diet. Food and water were given to all animals used for the experiments ad libitum. Animals were maintained at room temperature $\left(22 \pm 2^{\circ} \mathrm{C}\right)$ and were handled according to standard protocols for the use of laboratory animals. The studies were conducted according to the ethical guidelines of Committee for Control and Supervision of Experiments on Animals (Registration number 173/CPCSEA, dated 28 January, 2000), Government of India, on the use of animals for scientific research.

2.4.2. Experimental Design. The bioassay experiments were carried out according to AOAC [14] protocol. The animals were weighed, divided into six groups (D0, DI, DII, DIII, DIV, and DV) of six animals each, and housed individually in stainless steel screening bottom cages (permitting free dropping of faeces). Highly absorbent paper was placed under the cages to catch spilled food and to minimize contamination of faeces with urine.

The experimental diets (Table 1) containing $10 \%$ protein were prepared following ICN protocol [15]. The first group (D0) was given the $\mathrm{N}$-free basal diet and the second group (DI) was fed with reference diet (egg white), while the test groups (DII, DIII, DIV, and DV) were randomly allocated to the diets containing test ingredients (sun-dried and unsliced $A$. hybridus, cooked and sliced $A$. hybridus, sun-dried and unsliced A. cruentus, and cooked and sliced A. cruentus. 
TABLE 2: Minerals and heavy metals composition ( $\mathrm{mg} / \mathrm{Kg}$ ) of two differently processed amaranths species.

\begin{tabular}{|c|c|c|c|c|c|c|c|c|c|c|c|c|}
\hline Processing & $\mathrm{Na}$ & $\mathrm{K}$ & $\mathrm{Ca}$ & $\mathrm{P}$ & $\mathrm{Mg}$ & $\mathrm{Mn}$ & $\mathrm{Fe}$ & $\mathrm{Zn}$ & As & $\mathrm{Hg}$ & $\mathrm{Pb}$ & $\mathrm{Cd}$ \\
\hline \multicolumn{13}{|c|}{ A. hybridus } \\
\hline SDU & 6.185 & 697.3 & 307.7 & 111.5 & 111.8 & 0.117 & 0.624 & 3.027 & 0.024 & 0.109 & 0.007 & 0.002 \\
\hline CS & 3.549 & 298.7 & 535.5 & 110.4 & 102.9 & 0.914 & 2.912 & 10.04 & 0.026 & 0.137 & 0.018 & 0.001 \\
\hline \multicolumn{13}{|c|}{ A. cruentus } \\
\hline SDU & 3.368 & 796 & 422.5 & 173.6 & 106.5 & 0.462 & 3.402 & 48 & 0.025 & ND & 0.024 & ND \\
\hline $\mathrm{CS}$ & 3.913 & 323.2 & 576.8 & 79.56 & 88.47 & 0.597 & 5.685 & 38.22 & 0.037 & ND & 0.022 & ND \\
\hline
\end{tabular}

SDU: sun-dried and unsliced, CS: cooked and sliced, and ND: not detected.

TABLE 3: Proximate composition (g/100 g dry matter) of protein of reference (egg white) and differentially processed A. hybridus and A. cruentus.

\begin{tabular}{lccccc}
\hline Diet & Dry matter & Crude protein & Crude lipid & Crude fibre & Ash \\
\hline Egg white & $89.95 \pm 0.99^{\mathrm{ab}}$ & $80.05 \pm 0.85^{\mathrm{a}}$ & $1.07 \pm 0.74^{\mathrm{c}}$ & $1.73 \pm 0.20^{\mathrm{e}}$ & $6.89 \pm 0.05^{\mathrm{c}}$ \\
\hline \multicolumn{5}{c}{ A. hybridus } \\
\hline SDU & $89.58 \pm 0.025^{\mathrm{ab}}$ & $30.95 \pm 0.07^{\mathrm{dc}}$ & $3.80 \pm 0.39^{\mathrm{a}}$ & $6.02 \pm 0.65^{\mathrm{d}}$ & $15.43 \pm 0.07^{\mathrm{a}}$ \\
CS & $90.38 \pm 0.08^{\mathrm{a}}$ & $31.79 \pm 0.04^{\mathrm{c}}$ & $1.21 \pm 0.03^{\mathrm{c}}$ & $14.00 \pm 0.08^{\mathrm{a}}$ & $10.45 \pm 0.12^{\mathrm{bd}}$ \\
\hline \multicolumn{5}{c}{ A. cruentus } & \\
\hline SDU & $88.487 \pm 0.1^{\mathrm{b}}$ & $32.22 \pm 0.02^{\mathrm{b}}$ & $1.64 \pm 0.09^{\mathrm{bc}}$ & $8.76 \pm 0.15^{\mathrm{c}}$ & $9.67 \pm 0.04^{\mathrm{d}}$ \\
CS & $90.02 \pm 0.8^{\mathrm{ab}}$ & $25.65 \pm 0.01^{\mathrm{e}}$ & $2.58 \pm 0.07^{\mathrm{b}}$ & $12.18 \pm 0.66^{\mathrm{b}}$ & $9.27 \pm 0.60^{\mathrm{d}}$ \\
\hline
\end{tabular}

Results are expressed as mean \pm standard deviation. Means in the same column followed by the same letters are not significantly different at $5 \%$. DI: egg white (standard protein), SDU: sun-dried and unsliced, and CS: cooked and sliced.

2.4.3. Nutritional Evaluations. The absorbed nitrogen, true digestibility (TD), feed efficiency (FE), efficiency of food utilization (EFU), protein efficiency ratio (PER), and net protein ratio (NPR) were all computed as described by Pirman et al. [16].

2.4.4. Biochemical Assay. At the end of the experimental period (14 days), blood samples were collected following overnight fasting by cardiac puncture from chloroform anaesthetized rats into heparinised and nonheparinised tubes. The nonheparinised tubes were allowed to clot and were centrifuged at $3000 \mathrm{rpm}$ for $15 \mathrm{~min}$ to obtain the serum. These sera were assayed for alanine aminotransferase (ALAT), aspartate aminotransferase (ASAT), creatinine, albumin, and urea using SPINREACT kit. The heparinised blood was used for determination of some haematological parameters including red blood cells, white blood cells, platelets, and their different indices $[17,18]$.

2.5. Statistical Analysis. Statistical analyses were performed using graph pad prism version 5.00 software. Data were analysed by one-way analysis of variance (ANOVA), followed by Bonferroni post hoc test. Results are expressed as mean \pm standard deviation of replicated samples. Differences were considered significant at $P<0.05$.

\section{Results and Discussion}

\subsection{Results}

3.1.1. Minerals and Heavy Metal Content. The effects of processing treatments on mineral and heavy metals contents of two amaranths species are given in Table 2. Regardless of the processing methods, the level of $\mathrm{K}, \mathrm{P}$, and $\mathrm{Mg}$ remained high in both samples of sun-dried and unsliced amaranthus leaves. In both amaranths, increase of $\mathrm{Ca}, \mathrm{Mn}$, and Fe content was observed after cooking and slicing. Regardless of the amaranth, the levels of $\mathrm{Zn}$ and $\mathrm{Na}$ were relatively affected by processing methods. The levels of $\mathrm{Hg}$ and $\mathrm{Cd}$ were relatively high in A. hybridus regardless of the processing method.

3.1.2. Proximate Composition of Leafy Vegetables. The proximate composition of protein reference (egg white) and differentially processed $A$. hybridus and A. cruentus are presented in Table 3. The protein content of cooked and sliced A. cruentus had the least value $(25.65 \%)$ while the highest value $(32.22 \%)$ was recorded in sun-dried and unsliced $A$. cruentus leaves sample. The various food processing techniques caused significant differences $(P<0.05)$ between sundried and unsliced and cooked and sliced $A$. hybridus. Cooking improved the proximate composition of the vegetables relative to the sun drying and unslicing method. However, cooking and slicing significantly decreased protein level in $A$. cruentus as well as the total lipid of $A$. hybridus. The ash value for $A$. hybridus was influenced by the processing method, with a significant increase $(P<0.05)$ in sun-dried and unsliced sample $(15.43 \%)$, relative to the cooked and sliced sample $(10.45 \pm 0.12)$; meanwhile, there was no processingrelated significant variation $(P>0.05)$ in the ash content of A. cruentus.

3.1.3. Growth Performance and Protein Digestibility of Rats Fed with Processed Amaranths Leaves. The results of growth performance and protein quality on rats fed with different 
TABLE 4: Growth performance and protein quality of rats fed with diets containing processed A. hybridus and A. cruentus leaves.

\begin{tabular}{|c|c|c|c|c|c|c|}
\hline \multirow{3}{*}{ Parameters } & \multicolumn{6}{|c|}{ Experimental diets } \\
\hline & \multicolumn{2}{|c|}{ Standards } & \multicolumn{2}{|c|}{ A. hybridus-based diets } & \multicolumn{2}{|c|}{ A. cruentus-based diets } \\
\hline & D0 & DI & DII & DIII & DIV & DV \\
\hline Food intake $(\mathrm{g})$ & $21.92 \pm 2.92^{\mathrm{c}}$ & $68.56 \pm 9.04^{\mathrm{a}}$ & $54.70 \pm 5.35^{\mathrm{b}}$ & $73.46 \pm 5.57^{\mathrm{a}}$ & RNA & $31.63 \pm 5.77^{\mathrm{c}}$ \\
\hline Protein consumed (g) & RNA & $6.74 \pm 1.06^{\mathrm{ab}}$ & $5.47 \pm 0.53^{\mathrm{b}}$ & $7.34 \pm 0.55^{\mathrm{a}}$ & RNA & $3.16 \pm 0.57^{\mathrm{c}}$ \\
\hline weight gain $(\mathrm{g})$ & $-2.80 \pm 0.83^{\mathrm{d}}$ & $24.4 \pm 3.71^{\mathrm{a}}$ & $6.00 \pm 1.58^{c}$ & $13.60 \pm 1.67^{\mathrm{b}}$ & RNA & $-2.25 \pm 2.06^{\mathrm{d}}$ \\
\hline Feed efficiency (g/g) & RNA & $2.78 \pm 0.41^{\mathrm{b}}$ & $9.57 \pm 2.47^{\mathrm{a}}$ & $5.50 \pm 1.13^{\mathrm{b}}$ & RNA & RNA \\
\hline Faeces weight (g) & $2.20 \pm 0.44^{\mathrm{d}}$ & $7.40 \pm 1.67^{\mathrm{c}}$ & $14.00 \pm 1.00^{\mathrm{ab}}$ & $16.90 \pm 1.94^{\mathrm{a}}$ & RNA & $11.75 \pm 1.70^{\mathrm{b}}$ \\
\hline EFU (\%) & RNA & $36.5 \pm 5.30^{\mathrm{a}}$ & $10.93 \pm 2.39^{c}$ & $18.68 \pm 3.18^{\mathrm{b}}$ & RNA & RNA \\
\hline PER & RNA & $3.65 \pm 0.53^{\mathrm{a}}$ & $1.09 \pm 0.23^{\mathrm{c}}$ & $1.86 \pm 0.31^{\mathrm{b}}$ & RNA & RNA \\
\hline NPR & RNA & $3.27 \pm 0.14^{\mathrm{a}}$ & $0.63 \pm 0.23^{c}$ & $1.52 \pm 0.31^{\mathrm{b}}$ & RNA & RNA \\
\hline $\mathrm{TD}(\%)$ & RNA & $89.84 \pm 7.47^{\mathrm{a}}$ & $84.42 \pm 8.94^{\mathrm{a}}$ & $92.00 \pm 8.43^{\mathrm{a}}$ & RNA & $57.23 \pm 7.06^{\mathrm{b}}$ \\
\hline
\end{tabular}

Results are expressed as mean \pm standard deviation. Means in the same line followed by the same letters are not significantly different at 5\%. D0: protein-free diet, DI: egg white (standard protein), DII: sun-dried and unsliced A. hybridus, DIII: cooked and sliced A. hybridus, DIV: sun-dried and unsliced A. cruentus, and DV: cooked and sliced A. cruentus. TD: true digestibility, FE: feed efficiency, EFU: efficiency of food utilization, PER: protein efficiency ratio, NPR: net protein ratio, and RNA: results not available. All the group IV animals died before the end of experimental period.

processed diets of A. hybridus and A. cruentus leaves are presented in Table 4 . The rats fed with standard protein diet (DI) and cooked A. hybridus diet (DIII), respectively, had the highest food (68.56 and 73.46g) and protein (6.74 and $7.34 \mathrm{~g}$ ) intake and, consequently, showed the highest level of weight gain $(24.4 \mathrm{~g}$ and $13.60 \mathrm{~g})$ while those fed with cooked A. cruentus diet (DV) and protein-free diet (D0) significantly $(P<0.05)$ lost weight. Animals fed with sun-dried $A$. hybridus diet (DII) revealed the best feed efficiency while the highest value $(16.90 \mathrm{~g})$ of faeces weight was observed in animals fed with DIII. Weight of animals fed with diet DIV kept decreasing during experimental period and at the end, all the animals died. Animals fed with diet DIII significantly $(P<0.05)$ had the highest efficiency food utilization $(\mathrm{EFU})$, protein efficiency ratio (PER), and net protein ratio (NPR) compared to animals fed with DI. With the death of all animals fed with DIV diet, no data about the protein quality was recorded while neither feed efficiency, EFU, and PER nor NPR were available for these animals.

\subsubsection{Biochemical Parameters and Haematological Indices.} The results of the change in some serum enzyme activities and metabolites of rats fed with diets containing green leafy vegetables are shown in Table 5. Apart from DIII and DV, there was a significant decrease in serum activity of aspartate aminotransferase (AST) and alanine aminotransferase (ALT) of animals fed with formulated diets. The formulated diets did not influence the level of blood creatinine as compared to the control. However, these diets significantly increased $(P<0.05)$ the serum level of urea with diet DV having the highest value. On the contrary, these diets significantly decreased serum concentration of albumin with the effect of the diets being comparable. The results of the haematological parameters indicate that white blood cells (WBC), red blood cells (RBC), haemoglobin (HB), mean cell haemoglobin $(\mathrm{MCH})$, mean cell haemoglobin concentration (MCHC), mean platelet volume (MPV), and plateletcrit (PCT) were not significantly different $(P>0.05)$ between diet DI and diets DII, DIII, and DV. Animals fed with diets DII, DIII, and DV showed significant decrease $(P<0.05)$ in levels of lymphocytes (LYM) and platelets (PLT) when compared to rats fed with DI. In general, there was a significant $(P<$ 0.05 ) increase of mid-cell (MID) and granulocytes (GRAN) in groups fed with the formulated diets compared to the standard diet (DI).

\section{Discussion}

4.1. Mineral and Heavy Metals. The mineral analysis of treated leaves powder revealed the presence of eight (8) minerals in both samples, revealing them as excellent sources of macro- and micronutrients. The level of mineral content $(\mathrm{K}, \mathrm{P}$, and $\mathrm{Mg}$ ) was lower in cooked and sliced leaves when compared to sun-dried and unsliced samples. This is in line with the observations of Bakr and Gawish [19], Shahnaz et al. [20], and Oboh [21] that various conventional food processing techniques (cutting, bleaching, cooking, etc.) cause a decrease in the mineral content of vegetables. Losses of the mineral elements during boiling or cooking are generally attributed to the leaching of the cell content including minerals [19]. The result of mineral analysis of the vegetables suggests consumption of enough quantities to meet Recommended Daily Allowance (RDA). The value of $\mathrm{Na}$ in both sun-dried and unsliced and cooked and sliced samples was low compared to the value (300.06$600.83 \mathrm{mg} / \mathrm{kg}$ ) obtained by Makobo et al. [22] for sundried and bleached Amaranthus cruentus. $\mathrm{Na}$ is required for maintenance of fluid balance and osmotic pressure in the body for cellular activities $[23,24]$. The $\mathrm{K}$ content found in both vegetables regardless of the processing method was higher than $241.88 \mathrm{mg} / \mathrm{kg}$ reported by Ogbadoyi et al. [25] for Amaranthus cruentus. However, the result of this study reveals that $\mathrm{K}$ content dropped below those reported in the available literature and this suggests the consumption of large quantities of these vegetables in order to meet the RDA for minerals. For instance, adult minimum $\mathrm{K}$ requirement for 
TABLE 5: Biochemical parameters and haematological indices of rats fed with different processed A. hybridus and A. cruentus meal.

\begin{tabular}{|c|c|c|c|c|c|}
\hline \multirow{3}{*}{ Parameters } & \multicolumn{5}{|c|}{ Experimental diets } \\
\hline & \multirow{2}{*}{$\begin{array}{c}\text { Standard } \\
\text { DI }\end{array}$} & \multicolumn{2}{|c|}{ A. hybridus-based diets } & \multicolumn{2}{|c|}{ A. cruentus-based diets } \\
\hline & & DII & DIII & DIV & DV \\
\hline $\operatorname{AST}(\mathrm{U} / \mathrm{L})$ & $105.30 \pm 6.10^{\mathrm{a}}$ & $52.50 \pm 1.61^{b}$ & $35.53 \pm 2.70^{c}$ & RNA & $35.04 \pm 0.83^{\mathrm{c}}$ \\
\hline $\operatorname{ALT}(\mathrm{U} / \mathrm{L})$ & $27.25 \pm 0.59^{\mathrm{a}}$ & $17.85 \pm 0.10^{\mathrm{c}}$ & $21.00 \pm 1.01^{\mathrm{b}}$ & RNA & $21.29 \pm 0.80^{\mathrm{b}}$ \\
\hline Creatinine (mg/dL) & $1.41 \pm 0.64^{\mathrm{a}}$ & $0.99 \pm 0.26^{\mathrm{a}}$ & $1.24 \pm 0.31^{\mathrm{a}}$ & RNA & $0.58 \pm 0.38^{\mathrm{a}}$ \\
\hline Urea $(\mathrm{mg} / \mathrm{dL})$ & $34.01 \pm 0.58^{\mathrm{d}}$ & $38.81 \pm 1.09^{c}$ & $43.37 \pm 3.72^{\mathrm{b}}$ & RNA & $114.10 \pm 0.70^{\mathrm{a}}$ \\
\hline Albumin (g/dL) & $4.07 \pm 0.11^{\mathrm{a}}$ & $3.08 \pm 0.19^{\mathrm{b}}$ & $3.08 \pm 0.19^{\mathrm{b}}$ & RNA & $3.44 \pm 0.79^{\mathrm{ab}}$ \\
\hline $\operatorname{WBC}\left(10^{3} / \mu \mathrm{L}^{-1}\right)$ & $3.50 \pm 2.32^{\mathrm{a}}$ & $4.24 \pm 1.41^{\mathrm{a}}$ & $6.14 \pm 2.48^{\mathrm{a}}$ & RNA & $2.90 \pm 1.37^{\mathrm{a}}$ \\
\hline LYM (\%) & $84.24 \pm 1.80^{\mathrm{a}}$ & $70.72 \pm 4.95^{\mathrm{b}}$ & $76.80 \pm 4.92^{\mathrm{ab}}$ & RNA & $69.27 \pm 5.15^{\mathrm{b}}$ \\
\hline MID (\%) & $5.46 \pm 0.34^{c}$ & $11.38 \pm 2.95^{\mathrm{b}}$ & $9.30 \pm 0.95^{\mathrm{b}}$ & RNA & $16.30 \pm 2.55^{\mathrm{a}}$ \\
\hline GRAN (\%) & $3.95 \pm 1.15^{\mathrm{b}}$ & $17.9 \pm 2.48^{\mathrm{a}}$ & $16.73 \pm 6.65^{\mathrm{a}}$ & RNA & $13.73 \pm 2.95^{\mathrm{a}}$ \\
\hline $\operatorname{RBC}\left(10^{6} / \mu \mathrm{L}\right)$ & $5.31 \pm 0.94^{\mathrm{a}}$ & $4.66 \pm 2.68^{\mathrm{a}}$ & $5.30 \pm 1.13^{\mathrm{a}}$ & RNA & $6.69 \pm 1.05^{\mathrm{a}}$ \\
\hline $\mathrm{HB}\left(\mathrm{g} \cdot \mathrm{dL}^{-1}\right)$ & $11.46 \pm 1.91^{\mathrm{a}}$ & $12.94 \pm 1.06^{\mathrm{a}}$ & $13.76 \pm 1.83^{\mathrm{a}}$ & RNA & $15.2 \pm 2.25^{\mathrm{a}}$ \\
\hline $\mathrm{HCT}(\%)$ & $32.08 \pm 4.06^{\mathrm{a}}$ & $33.7 \pm 2.37^{\mathrm{a}}$ & $34.46 \pm 3.79^{\mathrm{a}}$ & RNA & $44.27 \pm 1.70^{\mathrm{b}}$ \\
\hline MCV (fL) & $60.96 \pm 3.46^{\mathrm{ab}}$ & $58.38 \pm 4.64^{\mathrm{b}}$ & $68.28 \pm 3.92^{\mathrm{a}}$ & RNA & $66.3 \pm 5.11^{\mathrm{ab}}$ \\
\hline $\mathrm{MCH}(\mathrm{pg})$ & $21.56 \pm 0.92^{\mathrm{a}}$ & $21.80 \pm 1.36^{\mathrm{a}}$ & $24.20 \pm 4.80^{\mathrm{a}}$ & RNA & $22.67 \pm 0.23^{\mathrm{a}}$ \\
\hline $\mathrm{MCHC}\left(\mathrm{g} \cdot \mathrm{dL}^{-1}\right)$ & $35.64 \pm 2.69^{\mathrm{a}}$ & $37.50 \pm 0.95^{\mathrm{a}}$ & $36.33 \pm 2.07^{\mathrm{a}}$ & RNA & $34.93 \pm 5.67^{\mathrm{a}}$ \\
\hline $\operatorname{PLT}\left(10^{3} / \mu \mathrm{L}\right)$ & $581.20 \pm 4.49^{\mathrm{a}}$ & $436.40 \pm 5.22^{\mathrm{d}}$ & $486.80 \pm 4.14^{\mathrm{c}}$ & RNA & $13.00 \pm 2.64^{\mathrm{b}}$ \\
\hline MPV (fL) & $7.78 \pm 1.51^{\mathrm{a}}$ & $8.12 \pm 0.53^{\mathrm{a}}$ & $7.92 \pm 0.50^{\mathrm{a}}$ & RNA & $7.80 \pm 0.61^{\mathrm{a}}$ \\
\hline PCT (\%) & $0.41 \pm 0.22^{\mathrm{a}}$ & $0.35 \pm 0.28^{\mathrm{a}}$ & $0.37 \pm 0.10^{\mathrm{a}}$ & RNA & $0.39 \pm 0.11^{\mathrm{a}}$ \\
\hline
\end{tabular}

Results are expressed as mean \pm standard deviation. Means in the same line followed by the same letters are not significantly different at $5 \%$. DI: egg white (standard protein), DII: sun-dried and unsliced A. hybridus, DIII: cooked and sliced A. hybridus, DIV: sun-dried and unsliced A. cruentus, and DV: cooked and sliced A. cruentus. WBC: white blood cell, LYM: lymphocytes, MID: mid-cells, GRAN: granulocyte, RBC: red blood cell, HB: haemoglobin, HCT: haematocrit, MCV: mean cell volume, MCH: mean cell haemoglobin, MCHC: mean cell haemoglobin concentration, PLT: platelets, MPV: mean platelet volume, PCT: plateletcrit, and RNA: results not available. All the group IV animals died before the end of experimental period.

health set by the $1989 \mathrm{RDA}$ is $2000 \mathrm{mg}$ daily [9]. Then to meet the RDA for this important mineral involved in cellular metabolism, water used in the boiling must be included in the meal preparations [25]. The level of Ca, Mn, and Fe observed in the cooked two species of vegetables clearly indicates that these vegetables are good sources of those minerals when compared to the values obtained for cereals [26].

Calcium and phosphorus are associated with each other for the growth and maintenance of bones, teeth, and muscles [27] while $\mathrm{Mg}$ is an important cofactor of enzymes involved in cell respiration, glycolysis, and transmembrane transporter [23]. Iron is an essential trace element for haemoglobin formation, normal function of central nervous system, and energy metabolism [28]. The highest value of zinc ( $48 \mathrm{mg} / \mathrm{kg})$ was found in sun-dried and unsliced $A$. cruentus. Therefore, the consumption of cooked and sliced $A$. hybridus in developing countries could correct $\mathrm{Zn}$ deficiency which is related to decreased growth in infants and children [29].

The values of $\mathrm{As}, \mathrm{Cd}, \mathrm{Pb}$, and $\mathrm{Hg}$ obtained in A. hybridus were lower than those obtained in the same species of amaranths by Oti Wilberforce and Nwabue [30] in the state of Nigeria. The vegetables analysed regardless of the treatment methods showed lower levels of the minerals and it can be suggested that the consumption of average amounts of these vegetables could not pose a health risk for the consumers as the values obtained are far below the permissible limits of $0.2 \mathrm{mg} / \mathrm{kg}$ (cadmium), $0.1 \mathrm{mg} / \mathrm{kg}$ (arsenic), and $0.01 \mathrm{mg} / \mathrm{kg}$ (mercury) [31].
4.2. Proximate Composition. The results of the proximate analysis showed that sun-dried and unsliced $A$. cruentus was the richest source of crude protein, while cooked and sliced A. hybridus had the highest value of crude fibre. Studies have shown that these leaves are usually cooked before consumption [32]. The cooked values were therefore of great importance. The cooked and sliced sample had the lower value than sun-dried and unsliced sample. The reduction could have been due to the different levels of heat treatment and the severity of thermal process during cooking where some nutrients were leached off by water during the process [33]. Krauss et al. [34] indicated that plant foods providing more than $12 \%$ protein calorific values are good sources of protein. Therefore, the leafy vegetables studied are good sources of protein and can be used as diet supplements for people suffering from undernutrition diseases if and only if those proteins could be bioavailable. The crude fibre content in both samples ranged from 6.02 to $14 \%$ with the highest level in cooked and sliced $A$. hybridus. These values are higher than those obtained by Mensah et al. [35] in A. cruentus (1.8\%) and Asaolu et al. [36] in A. hybridus (8.05\%). The plants can serve as good roughage in the intestine for better functioning of the alimentary system [37] since it had been reported that food fibre aids absorption of trace elements in the gut and reduces absorption of cholesterol. Besides, vegetables rich in fibre are natural broom for the body which help to prevent constipation, bowel problems, and piles [38]. 
4.3. Growth Performance and Protein Digestibility of Rats Fed with Processed Amaranths Leaves. Weight loss was observed with the animals fed with basal diets (D0) and cooked and sliced A. cruentus (DV) while 100 percent of mortality rates were recorded in the group fed with sun-dried and unsliced A. cruentus-based diet (DIV). For the basal diet, it is not surprising since it lacks protein as Cameron and Eshelman [39] showed that deficiencies in dietary protein slow growth and delay maturation. The loss in weight observed with rats fed with sun-dried and unsliced $A$. hybridus (DII), cooked and sliced A. hybridus (DIII), and cooked and sliced $A$. cruentus (DV) is then a consequence of lack of full utilization and poor protein quality indices such as low values of PER, NPR, and TD. Furthermore, it could be either due to the fact that plant protein can be encased in cellulose walls, which are hard to penetrate making proteins less accessible to digestive enzymes [40], or attributed to the rich sources of dietary fibre contained in those vegetables which are known to decrease protein utilization [41]. This finding is consistent with earlier report. Agbede et al. [42] reported that vegetables proteins have lower quality protein than the animal protein, and such a diet needs to be supplemented with another protein source relatively rich in the essential amino acids. The reduction in weight gain also implies that cooked and sliced A. cruentus can be used in weight reduction regimens. Studies have shown that weight reduction is one of the ways of reducing coronary risk incidence, as well as managing diabetes mellitus, dyslipidemia, hypertension, and obesity [34], and is one of the strategies for improving low high density lipoprotein cholesterol (HDL-C) levels. Those results are in line with the faeces. Indeed, the faeces bulk of animals fed with these vegetables based diets was higher than those of animals fed with the standard and nitrogen-free diets. This could be explained by the abundance of fibre content in the vegetables. Cummings [43] and EFSA [44] stated that dietary fibres contribute to an increase in faecal bulk with some beneficial physiological effect like the laxative effect, capacity to decrease gastrointestinal transit time, loose stools, bloating and distension, borborygmi, abdominal discomfort, and flatus [45]. Furthermore, faeces weight is inversely related to colon cancer [43].

The death of animal fed with sun-dried and unsliced $A$. cruentus-based diet could be probably due to the presence of high amount of antinutritional factors such as trypsin inhibitors, phytate, and polyphenols that could have interfered with metabolic processes by reducing the bioavailability of nutrients [46] and limiting the digestibility of plant protein [47] and can also provoke deleterious effects on many organs [48].

4.4. Biochemical Parameters and Haematological Indices. There were significant increases in serum alanine aminotransferase (ALT), albumin, and aspartate aminotransferase (AST) in rats fed with diet containing cooked and sliced A. cruentus and sun-dried and unsliced A. hybridus. This indicates possible damage of some organ such as liver and heart by those vegetables. ALT is regarded to be more specific indicator of liver inflammation, while AST may be elevated in diseases of other organs such as heart and muscle diseases
[49]. There was also a significant increase in the serum albumin in rats fed with diet containing cooked and sliced $A$. cruentus; this clearly indicates that $A$. cruentus may not cause liver damage since albumin is produced mainly in the liver. Except for the group fed with cooked and sliced A. cruentus $\left(0.58 \pm 0.038 \mathrm{mg} \cdot \mathrm{dL}^{-1}\right)$, the level of creatinine in other groups was higher than the normal values $\left(0.2-0.8 \mathrm{mg} \cdot \mathrm{dL}^{-1}\right)[50]$. This is an indication that the samples contained considerable amount of phytochemical compounds that may cause kidney related malfunctions.

The best $\mathrm{RBC}$ and $\mathrm{HB}$ values were observed with animals fed with diet containing cooked and sliced Amaranthus species. This shows that these processed leaves help in blood formation due to availability of crude protein and iron, meaning that there is no risk relative to the anaemia and related diseases with the consumption of the studied amaranth species. White blood cell count and MID cell are related to immune system and bone marrow and are indicators of the ability of an organism to eliminate infection [51]. The white blood cell of animal fed with sun-dried and unsliced and cooked and sliced A. hybridus-based diet was not significantly different to the reference diet, showing that the feed does not affect the immune systems of animal.

\section{Conclusion}

The present study clearly indicates that cooking method remains the best way for good utilization of these green leafy vegetables. It was also found that cooked and sliced $A$. hybridus compared to $A$. cruentus can better support growth performance. However, cooked and sliced A. cruentus and $A$. hybridus could be used in weight reduction regimes.

\section{Competing Interests}

The authors declare that they have no competing interests.

\section{Acknowledgments}

The authors acknowledged the financial assistance of the Department of Science \& Technology and the Ministry of External Affairs, Government of India, and FICCI for CV Raman International Fellowship for African Researchers grant offer.

\section{References}

[1] T. C. Mosha and H. E. Gaga, "Nutritive value and effect of blanching on the trypsin and chymotrypsin inhibitor activities of selected leafy vegetables," Plant Foods for Human Nutrition, vol. 54, no. 3, pp. 271-283, 1999.

[2] A. O. Fasuyi, "Nutritional potentials of some tropical vegetable leaf meals: chemical characterization and functional properties," African Journal of Biotechnology, vol. 5, no. 1, pp. 49-53, 2006.

[3] A. I. Ihekoronye and P. O. Ngoddy, Integrated Food Science and Technology for the Tropics, Macmillan Publishers, London, UK, 2nd edition, 1985. 
[4] J. M. C. Stevels, Légumes traditionnels du Cameroun, une étude agrobotanique, Wageningen Agricultural University Papers, Wageningen, The Netherlands, 1990.

[5] A. R. Olaposi and A. O. Adunni, "Chemical composition of three traditional vegetables in Nigeria," Pakistan Journal of Nutrition, vol. 9, no. 9, pp. 858-860, 2010.

[6] F. O. Orech, T. Akenga, J. Ochora, H. Friis, and J. AagaardHansen, "Potential toxicity of some traditional leafy vegetables consumed in Nyangoma Division, Western Kenya," African Journal of Food, Agriculture, Nutrition and Development, vol. 5, no. $1,2005$.

[7] F. I. Smith and P. Eyzaguirre, "African leafy vegetables: their role in the World Health Organization's global fruit and vegetables initiatives," African Journal of Food, Agriculture, Nutrition and Development, vol. 7, pp. 1-9, 2007.

[8] S. S. Sobowale, O. P. Olatidoye, O. O. Olorode, and O. K. Sokeye, "Effect of preservation methods and storage on nutritional quality and sensory properties leafy vegetables consumed in Nigeria," Journal of Medical and Applied Biosciences, vol. 2, pp. 46-56, 2010.

[9] H. D. Mepba, L. Eboh, and D. B. Banigo, "Effect of processing treatments on the nutritional composition and consumer acceptance of some Nigeria edible leafy vegetables," African Journal of Biotechnology, vol. 4, pp. 157-159, 2007.

[10] E. O. Udosen and U. M. Ukpanah, "The toxicants and phosphorus content of some Nigerian vegetables," Plant Foods for Human Nutrition, vol. 44, no. 3, pp. 285-289, 1993.

[11] P. Fellows, Food Processing Technology: Principles and Practice, Ellis Harwood Limited, West Sussex, UK, 1990.

[12] S. C. Noonan and G. P. Savage, "Oxalate content of foods and its effect on humans," Asia Pacific Journal of Clinical Nutrition, vol. 8, no. 1, pp. 64-74, 1999.

[13] B. Du, F.-M. Zhu, and F.-Y. Li, "Measurement and analysis of mineral components in grape wine by inductively coupled plasma-optical emission spectrometer," Advance Journal of Food Science and Technology, vol. 4, no. 5, pp. 277-280, 2012.

[14] AOAC, Association of Official Analytical Chemists. Official Method of Analysis of AOAC International, AOAC, Washington, DC, USA, 16th edition, 1997.

[15] ICN, International conference of nutrition, biochemicals catalog no. 103312 and no. 960219, Rome, Cleavaland, 1992.

[16] T. Pirman, M. Mari, and A. Orenik, "Changes in digestibility and biological value of pumpkin seed Cake protein after limiting amino acids supplementation," Izvorni znanstveni članak, vol. 49, no. 2, pp. 95-102, 2007.

[17] J. P. Benson and B. Cales, "Animal anatomy and physiology", in Laboratory Text Book, pp. 325-341, Wm.C. Brown Communication, Dubuque, Iowa, USA, 1992.

[18] H. Theml, Atlas de Poche d'Hématologie, Flammarion Médecine-Science, Paris, France, 2000.

[19] A. A. Bakr and R. A. Gawish, "Trials to reduce nitrate and oxalate content in some leafy vegetables. 2. Interactive effects of the manipulating of the soil nutrient supply, different blanching media and preservation methods followed by cooking process," Journal of the Science of Food and Agriculture, vol. 73, no. 2, pp. 169-178, 1997.

[20] A. Shahnaz, K. M. Khan, A. Munirm, and S. Muhammed, "Effect of peeling and cooking on nutrient in vegetables," Pakistan Journal of Nutrition, vol. 2, no. 3, pp. 189-191, 2003.

[21] G. Oboh, "Effect of blanching on the antioxidant properties of some tropical green leafy vegetables," LWT-Food Science and Technology, vol. 38, no. 5, pp. 513-517, 2005.
[22] N. D. Makobo, M. D. Shoko, and T. A. Mtaita, "Nutrient content of amaranth (Amaranthus cruentus L.) under different processing and preservation methods," World Journal of Agricultural Sciences, vol. 6, pp. 639-643, 2010.

[23] N. W. Tietz, A. B. Carl, and R. A. Edward, Test Book of Clinical Chemistry, W.B. Saunders Company, London, UK, 2nd edition, 1994.

[24] H. M. Aliyu and A. I. Morufu, "Proximate analysis of some leafy vegetables (Roselle, jute and bitter leaf)," International Journal of Food and Agricultural Economics, vol. 3, pp. 194-198, 2006.

[25] E. O. Ogbadoyi, A. Musa, J. A. Oladiran, M. I. S. Ezenwa, and F. H. Akanya, "Effect of processing methods on some nutrients, antinutrients and toxic substances in Amaranthus cruentus," International Journal of Applied Biology and Pharmaceutical Technology, vol. 2, pp. 487-502, 2011.

[26] H. Oumarou, R. A. Ejoh, R. Ndjouenkeu, and A. Tanya, "Nutrient content of complementary foods based on processed and fermented sorghum, groundnut, spinach, and mango," Food and Nutrition Bulletin, vol. 26, no. 4, pp. 385-392, 2005.

[27] M. Turan, S. Kordali, H. Zengin, A. Dursun, and Y. Sezen, "Macro and micro mineral content of some wild edible leaves consumed in eastern Anatolia," Acta Agriculturae Scandinavica Section B: Soil and Plant Science, vol. 53, no. 3, pp. 129-137, 2003.

[28] H. Ishida, H. Suzuno, N. Sugiyama, S. Innami, T. Tadokoro, and A. Maekawa, "Nutritive evaluation on chemical components of leaves, stalks and stems of sweet potatoes (Ipomoea batatas poir)," Food Chemistry, vol. 68, no. 3, pp. 359-367, 2000.

[29] K. H. Brown, J. M. Peerson, J. Rivera, and L. H. Allen, "Effect of supplemental zinc on the growth and serum zinc concentrations of prepubertal children: a meta-analysis of randomized controlled trials," American Journal of Clinical Nutrition, vol. 75, no. 6, pp. 1062-1071, 2002.

[30] J. O. Oti Wilberforce and F. I. Nwabue, "Heavy metals effect due to contamination of vegetables from Enyigba Lead Mine in Ebonyi State, Nigeria ," Environmental and Pollution, vol. 2, no. $1,2013$.

[31] WHO/FAO, Food Standard Programme Codex Alimentarius Commission 13th Session. Report of the thirty eight session of the codex committee on food hygiene: Houston, United States of America, ALINORM, 2007.

[32] W. S. Jansen Van Rensburg, S. L. Venter, T. R. Netshiluvhi, E. Van Den Heever, H. J. Vorster, and J. A. De Ronde, "Role of indigenous leafy vegetables in combating hunger and malnutrition," South African Journal of Botany, vol. 70, no. 1, pp. 52-59, 2004.

[33] J. O. Olusanya, Essentials of Food and Nutrition, Apex Books, Lagos, Nigeria, 2008.

[34] R. M. Krauss, P. J. Blanche, R. S. Rawlings, H. S. Fernstrom, and P. T. Williams, "Separate effects of reduced carbohydrate intake and weight loss on atherogenic dyslipidemia," The American Journal of Clinical Nutrition, vol. 83, no. 5, pp. 1025-1031, 2006.

[35] J. K. Mensah, R. I. Okoli, J. O. Ohaju-Obodo, and K. Eifediyi, "Phytochemical, nutritional and medical properties of some leafy vegetables consumed by Edo people of Nigeria," African Journal of Biotechnology, vol. 7, no. 14, pp. 2304-2309, 2008.

[36] S. S. Asaolu, O. S. Adefemi, I. G. Oyakilome, K. E. Ajibulu, and M. F. Asaolu, "Proximate and mineral composition of nigerian leafy vegetables," Journal of Food Research, vol. 1, no. 3, pp. 214218, 2012.

[37] G. M. Wardlaw and A. M. Smith, Contemporary Nutrition, McGraw-Hill International, New York, NY, USA, 7th edition, 2009. 
[38] J. Pallavi and M. Dipika, "Effect of dehydration on the nutritive value of drumstick leaves," Molecular Systems Biology, vol. 1, pp. 5-9, 2010.

[39] G. N. Cameron and B. D. Eshelman, "Growth and reproduction of hispid cotton rats (Sigmodon hispidus) in response to naturally occurring levels of dietary protein," Journal of Mammalogy, vol. 77, no. 1, pp. 220-231, 1996.

[40] V. R. Young and P. L. Pellette, "Plant proteins in relation to human protein and amino acid requirements," The American Journal of Clinical Nutrition, vol. 59, pp. 1203-1212, 1994.

[41] R. Modgil and M. Modgil, "Effect of feeding Chayote (Sechum edule) and Bottle Gourd (Lageneria siceraria) as a source of fiber on biological utilization of diet in rats," Journal of Human Ecology, vol. 15, pp. 109-111, 2004.

[42] J. O. Agbede, M. Adegbenro, O. Aletor, and A. Mohammed, "Evaluation of the nutrition value of Vernonia amygdalina leaf protein concentrates for infant weaning foods," Acta Alimentaria, vol. 36, no. 3, pp. 387-393, 2007.

[43] J. H. Cummings, "The effect of dietary fiber on fecal weight and composition," in CRC Handbook of Dietary Fiber in Human Nutrition, G. A. Spiller, Ed., pp. 263-349, CRC Press, Boca Raton, Fla, USA, 2nd edition, 1993.

[44] EFSA Panel on Dietetic Products Nutrition and Allergies, "Scientific Opinion on the substantiation of health claims related to wheat bran fibre and increase in faecal bulk (ID 3066), reduction in intestinal transit time (ID $828,839,3067,4699)$ and contribution to the maintenance or achievement of a normal body weight (ID 829) pursuant to Article 13(1) of Regulation," EFSA Journal, vol. 8, pp. 1817-1835, 2010.

[45] M. T. Flood, M. H. Auerbach, and S. A. S. Craig, "A review of the clinical toleration studies of polydextrose in food," Food and Chemical Toxicology, vol. 42, no. 9, pp. 1531-1542, 2004.

[46] P. O. Agbaire and O. O. Emoyan, "Nutritional and antinutritional levels of some local vegetables from Delta State, Nigeria," African Journal of Food Science, vol. 6, no. 1, pp. 8-11, 2012.

[47] V. A. Aletor, "Cyanide in Garri 2. An assessment of some aspects of the nutrition fed garri containing various residual cyanide levels," International Journal of Food Sciences and Nutrition, vol. 4, pp. 289-295, 1993.

[48] C. N. Esenwah and M. J. Ikenebomeh, "Processing effects on the nutritional and anti-nutritional contents of African locust bean (Parkia biglobosa Benth.) seed," Pakistan Journal of Nutrition, vol. 7, no. 2, pp. 214-217, 2008.

[49] D. E. Johnston, "Special considerations in interpreting liver function tests," American Family Physician, vol. 59, pp. 22232230, 1999.

[50] C. Johnson-Delaney, Exotic Animal Companion Medicine Handbook for Veterinarians, Zoological Education Network, Lake Worth, Fla, USA, 2005.

[51] J. A. Saliu, O. O. Elekofehinti, K. Komolafe, and G. Oboh, "Effects of some green leafy vegetables on the hematological parameters of diabetic rats," Journal of Natural Product and Plant Resources, vol. 2, pp. 482-485, 2012. 

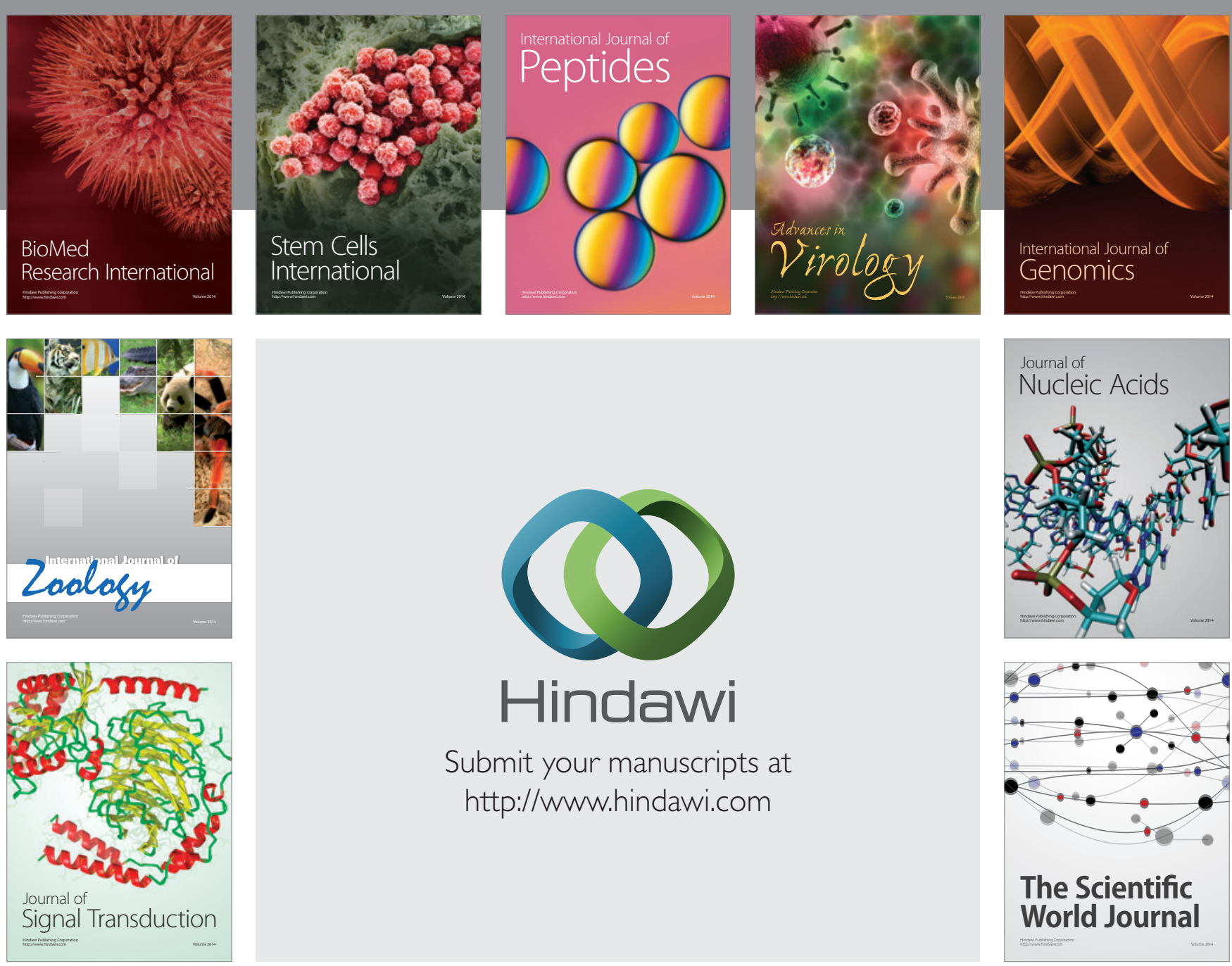

Submit your manuscripts at

http://www.hindawi.com
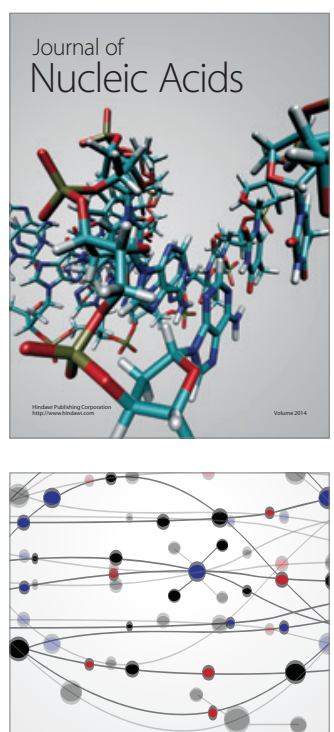

The Scientific World Journal
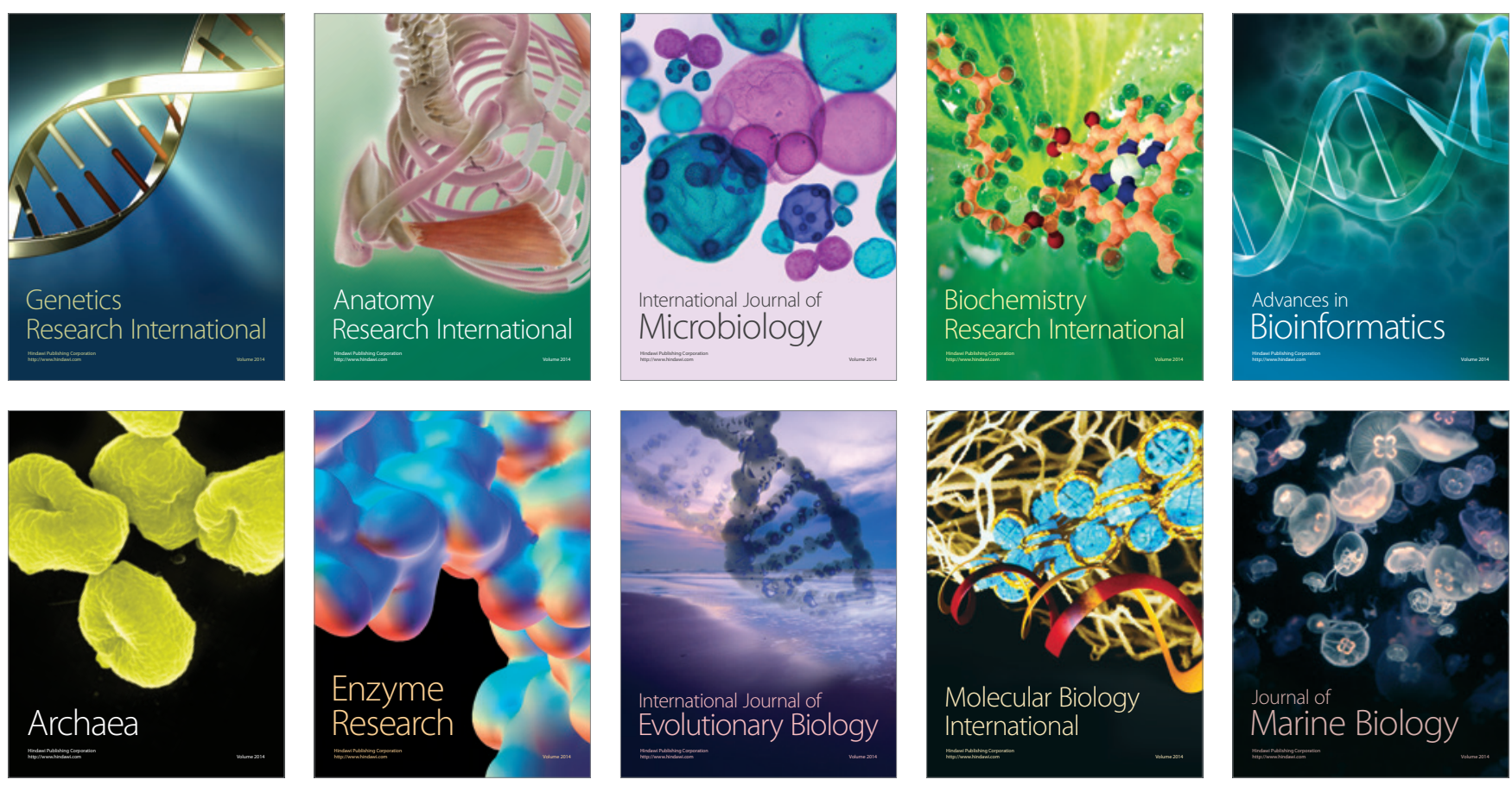